\title{
Anna Gnot
}

\section{Biografie pod specjalnym nadzorem}

Co prawda, takiej powieści, tj. takiego wielkiego utworu biograficznego, który posługując się naszą terminologią moglibyśmy nazwać powieścią, świat antyczny nie stworzył. Ale opracował szereg w największym stopniu istotnych form autobiograficznych i biograficznych, które wywarły ogromny wpływ na rozwój nie tylko europejskiej biografii i autobiografii, ale także całej powieści europejskiej. U podstaw tych form antycznych leży nowy typ czasu biograficznego i nowy obraz człowieka, który przechodzi swoją drogę życiową.

(Bachtin, 1974, s. 306)

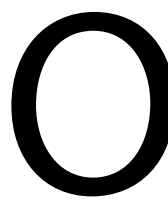

soby zajmujące się problematyką biografii natrafiają w swojej pracy na wiele trudności. Próba definiowania tego specyficznego gatunku nie jest łatwym zadaniem: ani w perspektywie synchronicznej, ani diachronicznej. Kwestią o zbliżonej wadze pozostaje refleksja na temat zakresu gatunków biograficznych. W szerszej perspektywie również biograficzność jako centralna lub peryferyjna właściwość tekstów kultury powinna wzbudzać zainteresowanie osób zajmujących się tymi kwestiami. Wyzwaniem w procesie badania biografii pozostaje zarówno określenie pozycji utworów biograficznych w ramach poszczególnych literatur narodowych, jak i fenomen ich niesłabnącej popularności na międzynarodowym rynku księgarskim. W tym kontekście nie powinniśmy także pomijać dalszych pytań dotyczących na przykład mechanizmów ideologicznego transferu, czyniących z biografii nośniki uniwersalnych wartości, udziału w procesie formowania granicy pomiędzy tym, co prywatne, a tym, co społeczne, czy też ścisłych relacji między literaturą 
biograficzną a autobiograficzną. W niniejszym numerze czasopisma "Adeptus", objętym patronatem Ośrodka Karta i Czeskiej Bibliografii Literackiej, postanowiliśmy postawić młodych badaczy i młode badaczki przed tego rodzaju wyzwaniami, pozostawiając im oczywiście możliwość zaproponowania własnych ujęć i sposobów obserwacji materiału biograficznego, wykraczających poza zaproponowaną skalę tematycznych oraz metodologicznych możliwości podjęcia się takiego zadania.

W ujęciu cytowanego powyżej Michaiła Bachtina biografia już w starożytności stanowiła gatunek o niepodważalnym znaczeniu dla rozwoju poszczególnych społeczności w ramach kultury helleńskiej i rzymskiej. Bachtinowska koncepcja biografii odbiega od współczesnego jej rozumienia jako formy literackiej, eksplorującej losy wyjątkowych członków konkretnej wspólnoty. W ujęciu rosyjskiego literaturoznawcy biografia staje się bowiem - początkowo również jako gatunek czysto retoryczny - symbolicznym aktem aktywnego wstąpienia w życie publiczne. Już antyczne mity przynosiły inspirujące opowieści o bohaterskich czynach bogów i herosów, ale to dzięki aktom biograficznej prezentacji status wyjątkowości osiągnęły również losy zwyczajnych śmiertelników, którzy - dzięki właściwym tylko sobie cechom charakteru - mierzyli się z przeciwnościami losu, a tym samym przekraczali granice życia nie tylko indywidualnego, lecz także publicznego.

Współcześnie biografie stanowią unikatowe świadectwa wyjątkowości grup poszukujących swoich przedstawicieli godnych literackiego opisu. To losy tych bohaterów oferują inspirującą i zakorzenioną w lokalnych uwarunkowaniach aktualizację uniwersalnych wartości. W tym kontekście biografie funkcjonują jako teksty pośredniczące w procesie tworzenia i kształtowania indywidualnej oraz kolektywnej pamięci, przejawiającej się w różnych wariantach, gatunkach bądź uwarunkowanych historycznie i geograficznie konwencjach. Proponując temat niniejszego numeru, nie chcieliśmy ograniczać inwencji autorek i autorów wyłącznie do poruszania zagadnień o czysto literackim charakterze, ale również zachęcić ich do poszerzenia literackiego pola funkcjonowania gatunków biograficznych i przekraczania jego granic, poprzez sięganie do sąsiednich obszarów: językoznawstwa, kulturoznawstwa, politologii, socjologii czy religioznawstwa.

W artykule Saidiya Hartman i krnąbrne biografie. Co czarne herstorie moga zrobić dla polskiego «zwrotu ludowego»? Łukasz Kiełpiński koncentruje się na metodzie krytycznej fabulacji, opracowanej przez amerykańską badaczkę studiów afroamerykańskich - Saidiyę Hartman. Badacz podejmuje refleksję na temat zastosowania tego ujęcia, wykorzystywanego do rekonstrukcji biografii byłych czarnoskórych niewolnic, na polskim gruncie i w kon- 
tekście zwrotu ludowego. Perspektywą przyjętą w artykule Alicji Budzyńskiej Pomiędzy autobiografiq a mitem: opowiadania Oty Pavla na tle twórczości pisarzy polsko-żydowskich jest komparatystyczne spojrzenie na twórczość Oty Pavla, Brunona Schulza i Artura Sandauera. Wspólnym mianownikiem rozważań badaczki jest wykorzystanie w twórczości wspomnianych autorów konwencji autobiograficznej. W tekście Mozaikowe tożsamości Mai Deren. Złożoność perspektyw w badaniu biografii artystki Izabella Tyborowicz przygląda się opracowaniom biograficznym, dotyczącym życia tej amerykańskiej artystki, szukając w jej twórczości wątków autobiograficznych, zwłaszcza związanych z jej emigranckim, ukraińsko-żydowskim pochodzeniem. Postaci lwowskiego arcybiskupa Józefa Bilczewskiego jest poświęcony artykuł Tymoteusza Króla Polski patriota z niemieckiej kolonii. Analiza tekstów hagiograficznych o Józefie Bilczewskim. Autor analizuje biograficzne opracowania życia i działalności przyszłego świętego katolickiego w kontekście jego pochodzenia, a zwłaszcza w świetle polsko-niemieckiego sporu o przynależność narodową tej postaci. W swoim artykule Reading 1908 Buryat Schoolbook on Buddhism in the Light of its Socio-Cultural Setting Ayur Zhanaev komentuje kontekst powstania i recepcji traktatu Zwięzła wykładnia religii Buddy Siakjamuniego do nauczania dzieci buriackich. Autor, poza analizą pierwszego podręcznika dla szkół świeckich w Buriacji, omawia również życiorys jego autora, lamy Danja-a Erdeniy-eba oraz prezentuje niepublikowany dotąd przekład omawianego tekstu źródłowego. Piotr Szatkowski w artykule The language practices of the Prussian-language revivalist family based on the short-term observation na podstawie, wykorzystywanej w badaniach nad wielojęzycznością, metody opisu biografii językowej obserwuje praktyki, których celem jest rekonstrukcja języka pruskiego. Autor prezentuje wyniki badania terenowego, przeprowadzonego wśród współczesnych aktywnych użytkowników tego języka, z uwzględnieniem wzajemnych polsko-pruskich wpływów językowych. Ostatnim, i pozostającym poza tematem numeru, artykułem jest Kilka uwag o ekwiwalencji międzyjęzykowej, autorstwa Romana Tymoshuka. Autor koncentruje się tu na kwestii frazeologicznej ekwiwalencji pomiędzy językiem ukraińskim a polskim, analizowanej za pomocą metod językoznawstwa korpusowego. Prezentowany numer domyka tekst Doroty Karwackiej-Pastor opublikowany w dziale Recenzje i omówienia. Autorka recenzuje w nim biografię Tadeusza Dołęgi-Mostowicza Parweniusz z rodowodem pióra Jarosława Górskiego.

Wszystkie opublikowane w niniejszym numerze prace reprezentują nieortodoksyjne spojrzenia na problematykę biografizmu oraz otwierają obszary, w których jej badanie nie jest tradycyjnym, oczywistym podejściem. Autorki i autorzy udowadniają, że szeroki zakres 
ich naukowych zainteresowań kreuje przestrzeń dwukierunkowej synergii - kiedy rodzima tradycja badań nad biografistyką może być z sukcesem wykorzystana do analizy utworów reprezentujących inne kultury oraz kiedy badawcza ciekawość inspiruje do wykorzystywania metod innowacyjnych na polskim gruncie. Pozostaje nam mieć nadzieję, że tego rodzaju różnorodność tematów oraz ujęć badawczych może stać się już w tym momencie kontrargumentem wobec głosów o kryzysie polskiej refleksji biografistycznej.

\section{Bibliografia:}

Bachtin, M. M. (1974). Czas i przestrzeń w powieści (J. Faryno, Tłum.). Pamiętnik Literacki, 1974(4), 273-311.

\section{Citation:}

Gnot, A. (2021). Biografie pod specjalnym nadzorem. Adeptus, 2021(18), Article 2724. https://doi.org /10.11649/a.2724

\section{Publication History:}

Received: 2021-12-30; Accepted: 2021-12-30; Published: 2022-01-17 